\title{
Mission as evangelism and as development? Some perspectives from the Lord's Prayer
}

\section{Ernst M. Conradie*}

\begin{abstract}
This essay builds on the conference on "Mission in the 21th century: New models and strategies in a world of diversity" held in Livingstone, Zambia from 25 March to 1 April 2004. It offers some background to the tension between mission as "evangelism" and as "development" which was addressed at this conference. It then describes some of the insights emerging from this conference) with specific reference to the description of mission as "crying and struggling with others to live today with dignity. "It provided some perspectives on this description on the lbasis of an exegesis of the second half of the lard's prayer. The conclusion to the essay suggests that further reflection is required on the relationship between soteriology and missiology.
\end{abstract}

\section{Introduction}

The United Church of Zambia Theological College hosted an international conference on "Mission in the 21st century: New models and strategies in a world of diversity" in Livingstone, Zambia from 25 March to 1 April 2004. The conference organizers described the purpose of the conference in the following way: "to explore and examine the commonalities and tensions between mission as evangelism and mission as development as it has been and is being experienced in many of the once politically colonized and now economically colonized countries of the south." Given the numerous stark contemporary challenges that churches have to address, the conference had to reflect on what it means to proclaim and practise the gospel today. Participants from each continent were invited in order to hear how the tension between mission as evangelism and mission as development is understood and addressed in various contexts. The conference organizers also suggested that this conference would do some preparatory work towards the Conference on World Mission and Evangelism (CWME) organized by the World Council of Churches (WCC) in Athens in May 2005.

\section{South African missiological discourse on mission as "evangelism" and as "development".}

The tension which the conference organizers identified between mission as "evangelism" and as "development" describes an old missiological debate in somewhat revised terminology. In South Africa this debate was addressed in the 1980s, especially by David Bosch, the doyen of missiology in South Africa.

The tension between "evangelical" and "ecumenical" models of mission structures the argument of Bosch's first major work, Witness to the world (1980).1 He describes

1 David J. Bosch, Witness to the world: The Christian mission in theological perspective, Atlanta, Georgia: John Knox, 1980. 
various characteristics of each of these contrasting models of mission and then shows how the emergence of these models may be understood in terms of the history of missiological reflection. He concludes that the "evangelical" approach to mission may lead to a "narrowing down" of the scope of the gospel, while the "ecumenical" approach may lead to a "watering down" of the gospel. Like many other missiologists, Bosch does not want to choose one of these polar opposites. In his own description of God's mission, Bosch suggests that the scope of the witness of the church (marturia) should include proclamation (kerugma), fellowship (koinonia) and service (diakonia).

In a further essay Bosch compared the models of mission that prevailed at the CWME conferences in Melbourne (May 1980) and the Consultation on World Evangelism in Pattaya, Thailand (J une 1980).2 In this essay Bosch offers a table of some of the contrasting emphases in these two models of mission. It may be helpful to list some of these features here:

2 See David J. Bosch, "In search of mission: Reflections on 'Melbourne' and 'Pattaya"' Missionalia Vol 9, No 1, 1981, pp. 3-18. Also Phil J. Robinson, "Die Belhar-belydenis van 1982 in sendingperspektieF in G.D. \& D.J. Smit (eds.), 'n Oomblik van waarheíd, Kaapstad, Suid-Afrika, Tafelberg, 1984, pp. 49-59. 
Melbourne

Emphasizes the present

God is revealed through contemporary Concerned about the witness where events

Emphasizes orthopraxy

The world is the arena of God's actions Emphasizes the credibility of the church the church $u$

Divides the world between rich and
Starts with human disorder Social service forms part of Christian poor, oppressors mission and oppressed

Social ethics is primary $\operatorname{Sin}$ is a Is attracted towards socialism collective matter

Pattaya Emphasizes the human nature of Jesus

Emphasizes the past and the future Draws attention to the universal Starts with God's plan presence of Christ

God is revealed through Christ and the Kerugma is primary, leads to koinonia Word Emphasizes orthodoxy and diakonia Emphasizes justification and redemption Hears the needs of Social service falls outside Christian lost souls Views humans from the mission

Personal ethics is primary

$\mathrm{Sin}$ is an individual matter perspective of sin Evaluates the world negatively Clear boundaries drawn between church and world The church Kerugma supports koinonia and is the arena of God's actions diakonia Emphasizes liberation Emphasizes the opportunities of the church Concerned about the witness Hears the needs of the poor and where is church is not Divides the oppressed world between various population or Views humans from a creation ethnic groups perspective Is attracted towards capitalism Evaluates the world positively Emphasizes the divine nature of J esus No clear boundaries drawn between Draws attention to the uniqueness of church and world

In his magnum, opus, Transforming mission ${ }^{3}$ Bosch no longer employs the distinction between evangelicals and ecumenicals. Instead, he adopts the paradigm theory of Thomas Kuhn, as adapted for theology by Hans Küng, in order to survey various paradigm shifts in the history of missiology. Almost 150 pages of this work are devoted to a chapter on elements of an emerging ecumenical missionary paradigm. Bosch is clearly convinced that all missionary activities have to follow an ecumenical approach and should include evangelism (p. 409-420) as well as the quest for justice (p. 400-409) and liberation (p. 432447). It is worthwhile to note that no sections are devoted to "development" (the word is not included in the subject index), the integrity of creation, health issues or gender relations. There is a section calling for a comprehensive notion of salvation in which these aspects of mission may perhaps find a place and which may offer one way of integrating the concerns of both "evangelism" and "development." In the final section of this essay I will return to such a comprehensive notion of salvation.

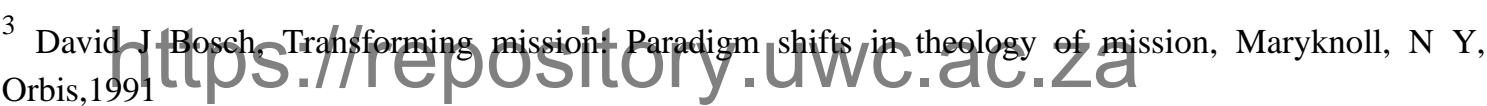




\section{The contribution of Livingstone 2004: Mission as "crying and struggling with others to live today with dignity".}

In the papers that were read at the Livingstone conference it was repeatedly noted that mission as "evangelism" and mission as "development" cannot be separated. However, it was also repeatedly noted that there is indeed, often a tension between these two aspects of mission. Any analysis of the missionary activities of churches will show that the intention of such activities is often focussed on the one or the other. There is also a widespread tendency to define the purpose of the one in terms of the other. For some, the church has to give bread to the hungry so that they can hear and respond to the gospel proclaimed by the church. For others, the very content of the gospel includes giving bread to the hungry. The development agenda is born from the proverbial recognition that it is insufficient to give fish to the hungry. It is also necessary to teach the hungry how to fish, to help them to acquire a fishing rod, to ensure equal access to the fishing waters and to address the problem of overfishing.

The conference organizers were therefore correct in identifying tensions between "mission" as "evangelism" and as "development". However, as many conference participants noted, each of these three terms is highly contested and in constant need of redefinition. Definitions of these terms simply cannot be imposed on others. Not surprisingly, some would opt to avoid such terms completely. This also suggests the need to continuously search for new categories to describe the responsibility of churches in their local and regional contexts amidst the numerous contemporary challenges that they have to address.

Given these observations, the conference appointed an interim working group to digest the theological insights emerging from the various papers of presenters, responders and group discussions. This "theological reflection" working group consisted of Ivone Gebara (Brazil, convenor), Xolile Simon (South Africa) and Ernst Conradie (South Africa). Two further groups were appointed to summarize the contemporary challenges to the mission of the church and to suggest practical guidelines for implementation in missionary discourse and praxis. All three working groups reported back to a plenary session, followed by intensive group discussions and reports from these group discussions to a final plenary session. In the discussion below, I will offer my own synthesis of the report from the working group on theological reflection, and further insights emerging from the group discussions and the final plenary session. It should, therefore be noted that this synthesis has not been officially endorsed by the conference organizers or participants. 
In the search for a new vocabulary to describe the role and responsibility of the church in contemporary society the theological reflection working group proposed the following description (not so much a new definition) of mission: "To participate in God's mission is to be crying and struggling with others to live today with dignity."

This description calls for further clarification on each of the terms that are used

\section{To participate in God's mission ...}

This formula is the product of ecumenical discourse on mission over several decades. To speak of God's mission is to realize that mission is not primarily the work of the church but the work of God. ${ }^{4}$ God's project is to establish the reign of God, not the church, as Adolfo Ham observed in his paper on the Cuban context during the Livingstone conference. The church may become one of the instruments used by the Holy Spirit in God's own mission to bring comprehensive well being to the world, to the whole earth community and to its human inhabitants.

\section{Why would the church be crying?}

It is not difficult to list some of the enormous challenges that churches and local communities are confronted with today. There is the immense plight of poverty: unemployment, hunger, malnutrition, famine, the widening gap between the affluent and the poor and economic injustices. In several contexts political and economic forms of oppression are prevalent. Accordingly, the conference organizers refer to "the once politically colonized and now economically colonized countries of the south." Furthermore, one may mention the many contemporary manifestations of violent conflict: domestic violence, rape, patriarchal oppression, the abuse of children, racial conflict, incidences of ethnic and tribal violence, religiously motivated violence, ongoing civil wars, various forms of violent crime including murder, hijacking and armed robbery, the spite of terrorist activities and suicide bombers, and finally the wars that have been declared to fight terrorism in the name of pax Americana. One may add to this a long list of forms of environmental destruction. In the light of these challenges the description of the social agenda of the church in terms of "J ustice, Peace and the Integrity of Creation" is certainly not outdated. The conference also devoted specific attention to various health threats, including malaria, tuberculosis and, especially, the devastating plight of the HIV/AIDS pandemic on the African continent. Finally, Marlene Wilkinson, in a moving presentation on the plight of Korean women, addressed the problem of "Han", the extreme shame and stigma imposed on various marginalized groups, and the need for Han-puri, that is, an exorcising of Han and an embracing of those who are stigmatized in this way.

\footnotetext{
${ }^{4}$ Ibid., pp. 389-393.
} 
To list these predicaments in this way does not by itself lead people to be crying with others. What is required is to identify and recognize the actual problem for what it is, to accept ownership for the particular problem (one cannot do so for all possible problems), to confess guilt - where appropriate - for a complicity in the problem, to have a heart of compassion for the suffering of the other, to demonstrate this with acts of solidarity with such an "other" and to challenge the ideological underpinnings which aggravates many of these problems.

\section{To be crying...}

To be crying with others may be an expression of suffering, compassion, empathy, sympathy and perhaps also of guilt. Crying may be a form of weeping that brings in its wake catharsis, relief and healing. It may also be part of a period of mourning or an aspect of lamenting. In a somewhat different mode, crying may also be an expression of righteous indignation, of anger, for example over injustices that have been inflicted on others. Crying may also be expressed in the context of prayer. A prayer may be a cry directed to God. This would be epitomized by the Lord's Prayer (see the discussion below). Such crying may not only be directed to God, but also to the "principalities and powers", the institutions that are maintaining an unjust status quo. It may be helpful to observe that such a response of crying and praying would be the opposite of a response to suffering that would fall into the traps of complaining, blaming, complacency or silencing.

\section{To be struggling ...}

Crying is not the only relevant response to the predicaments that churches are faced with. There is also a need for witnessing, learning, celebrating, thanking, working and serving. To be crying with others implies to be with others, perhaps to be others while struck in silence, much in the way that Ezekiel sat with exiles at Tel-Abib, stunned for seven days. However, to be crying with others certainly cannot mean to remain sitting around, doing nothing. Especially in the mode of praying, such a crying should be the wellspring for working, for a commitment to transformation, for taking responsibility, for helping, for participating in a struggle towards "J ustice, Peace and the Integrity of Creation." The relationship between crying as praying and struggling is captured by the classic Christian motto: Ora et labora, prayer and work. This calls for further theological reflection on the relationship between grace and transformation, between God's work in us and our work in the world, and between justification and sanctification.

\section{With others ...}

In contemporary philosophy and theology there is a wealth of discourse on the category of "the other." One salient point that is repeatedly made in such discourse is the need to respect the otherness of the other. This implies that the

\section{https://repository.uwc.ac.za}


other should not be reduced to an extension of my own gender, race, language, ethnic group, political party, culture, faith or religious tradition. To be crying with others is to show solidarity with others. It is not necessary to specify the referent of the "others" here, but such others would certainly include the poor, oppressed and marginalized, the helpless and the hungry, widows and orphans, the imprisoned and the disabled. The "other" includes those inside and outside Christian communities. The other does not only include humankind but also other kind in the earth community. Moreover, the others may also include our biological and spiritual ancestors, our communion with the saints and our responsibilities towards future generations.

\section{To live ...}

The World Council of Churches introduced a programme towards a "theology of life" in the 1990s. ${ }^{5}$ This programme focused on grass roots experiences of the struggle for life. A theology of life expresses the need for a celebration of the gift of life amidst the many stark threats to life. Such a theology of life is born within the context of a struggle for survival amidst the threats of death. Within the struggle between life and death, a theology of life affirms faith in the God of life and denounces the idols of death. It emerges from the experiences of those for whom life is denied and in solidarity with these struggles. It seeks a life that is more than biological existence; a life that is characterized by self-sufficiency and cultural, spiritual, political, economic and ecological sustainability. Life is understood here concretely to include land, houses, work, food, health, education, environment, participation in social life, and cultural and religious celebration. ${ }^{6}$ The struggles of the helpless for fullness of life in this way exemplify the struggle for survival of humanity and the whole "community of life " on earth.7 Such a notion of life allows for joy and celebration, precisely in the

\footnotetext{
${ }^{5}$ For literature on the notion of a "theology of life" within the context of the World Council of Churches, see the following contributions: Martien E. Brinkman, "A theology of life: Open questions", Exchange, Vol. 24, 1995, pp 176-183 Wesley Granberg-Michaelson, "Towards a theology of life", Reformed World, Vol 44,1994, pp 199-110 Lewis S Mudge, The church as moral community Ecclesiology and ethics in ecumenical debate, New York, Continuum, 1998 Konrad Raiser, To be the church Challenges and hopes for a new millennium, Geneva, World Council of Churches, 1997 Lariy L Rasmussen, "Theology of life and ecumenical ethics" in David G Hallman (ed ), Ecotheology Voices from South and North, Geneva World Council of Churches, 1994, pp 112129 Martin Robra, "Theology of life — Justice, Peace, Creation An ecumenical study". Ecumenical Review, Vol 48, No 1, 1996, pp 28-37 Pablo Richard, "A theology of life Rebuilding hope from the perspective of the South" in K C Abraham \& B Mbuy-Beya (eds). Spirituality of the Third World, Maiyknoll, New York, Orbis Books, 1994 Julio de Santa Ana, "Elements for a theology of life", Exchange Vol 24, 1995, pp 159175

${ }^{6}$ See Richard, "A theology of life", op cit, p 95

${ }^{7}$ For the notion of a community of life, see Harvey Sindima, "Community of life", The Ecumenical Review, Vol 41, No 4, 1989, pp 537-551
} 
midst of scarcity. An appreciation for the gift of life has to face up to the reality and the inevitability of death. To suggest the need to live with dignity would therefore include the need to be able to die with dignity, for example, amidst the stigma associated with HIV/AIDS.

Rooted in grass roots experiences of conflict, injustice and degradation, a theology of life seeks to offer thanks and praise to God's gracious gift of life in fellowship with all other living creatures. A life-centred ethos, based on such a theology of life, needs to reflect not only on a reverence for life (Albert Schweitzer), especially for the weaker, more vulnerable forms of life (an extension of the "preferential option for the poor"), but also on the material base of creation, that is, the material goods that permit life. ${ }^{8}$ A spirituality of life perceives in land, health, housing and work that enhances life, manifestations of God's glory. 9

In this task women play a crucial role to give birth, to nurture life and to create the necessary conditions for life in community to flourish. In an African context, Bernadette Mbuy- Beya describes a life-centred spirituality for women:

She gives life. Out of the child that she carries in her womb and whom she brings into the world, she tries to make the beginnings of a man or woman. She initiates the child to speech, to the mother tongue, to life in society and to spiritual and cultural values. In traditional society, the task of tilling the field is entrusted to the woman. She holds the secrets of the earth's fertility and develops a spirituality linked to the earth, which is expressed through songs and prayers to God at the beginning of each season. Protectress of life, she also plays the role of mediatrix in her family and her circle. She joins other women to try and ward off death that comes through war or family conflicts. She helps preserve social order by respecting the traditions which favor life..$^{10}$

\section{Today...}

The emphasis on the present is perhaps one of the most interesting but, possibly, also the most controversial aspects of the description of mission

\footnotetext{
${ }^{8}$ In his ground-breaking essay on an ethics of life, Larry Rasmussen identifies two aspects of the material base of life 1) the need for space, an adequate habitat for life to flourish, and 2) the use and abuse of power in sharing this space with other creatures See Rasmussen, "Theology of life and ecumenical ethics", op cit

${ }^{9}$ For a more detailed discussion of such a theology of life, see Ernst M Conradie, "Eschatological dimensions of a theology of life" in A van Egmond \& D van Keulen (eds). Christian hope in context Volume 1 Studies in Reformed Theology Volume 4, Zoetermeer, Nederland, Meinema, 2001, pp 163-204

${ }^{10}$ See my essay on the need for a "contemporary theologv": Ernst M. Conradie, "The responsibility of engaging in contemporary theology: A few observations", Scriptura 86, 2004, pp. 252-270.
} 
mentioned above. The emphasis here is on living life in the present, with cognizance to the past and with eyes that are open towards the future. It suggests the need to balance past, present and future. This emphasis on today implies a critique of the (Western?) orientation towards the future and a retrieval of an (African and Latin American?) celebration of life amidst the forces of death.

This emphasis on the present does not imply a realized eschatology that demands an immediate realization of God's promises and God's reign. Although the task of the church is indeed to alleviate future suffering as far as this is possible, Christian eschatology cannot only be orientated towards the future. Even if a society that would epitomize "Justice, Peace and the Integrity of Creation" may be established somewhere in the future, only those who are alive then will benefit from it. Such a society would not and cannot bring solace to the victims of the past. The victims of a thousand past generations cannot be sacrificed for the sake of later generations. Any adequate Christian eschatology has to focus on God's promises for a better future and on God's judgement over past injustices. An adequate Christian eschatology has to speak of God's presence in and with all times, since all times are and remain present with God. These observations may help to retrieve the eschatological significance of each moment in human history and in the history of the earth and the universe. If every moment is precious for God, this calls on us to be crying with others in order to live and to die today with dignity.

The emphasis on time (today) and place (here) also suggests the need to understand and analyze our present context. This is a prerequisite for a contextualised theology. The question has to be: "Who is God?" and "What is God doing today?" What is God doing in our own lives and the life of this (extended) family, this community, this congregation, this country and this bioregion?11

\section{With dignity...}

The concept of human dignity has often been related to an affirmation that every person has been created in the image of God. Each human being, female and male, the enslaved and the free, deserves, as a bearer of the image of God, to be treated with dignity and respect. Human dignity is the presupposition of human rights discourse. As Gregory of Nazianz affirms, "One same Creator for man and woman. For both the same clay, the same image, the same law, the same death, the same resurrection." 12 This moral significance of being created in the image of God is also emerging in new contexts, including the struggle towards the

\footnotetext{
${ }^{11}$ See my essay on the need for a "contemporary theology": Ernst M. Conradie, "The responsibility of engaging in contemporary theology: A few observations", Scriptura 86, 2004, pp. 252-270.

${ }^{12}$ Quoted in Mercy Amba Oduyoye, Hearing and knowing: Theological reflection* on Christianity in Africa, Nairobi, Kenya, Acton Publishers, 2000. p.133.
} 
abolition of slavery and with reference to the stigmatization of those who are HIV positive, people who are physically or mentally handicapped and victims of rape, crime or gangsterism. Moreover, the notion of the image of God has a democratizing and an egalitarian thrust. Every person is created in the image of God - not only the elite or the powerful. Every person is God's representative on earth. Whoever touches another human being with malicious intent touches Godself.

In African reflection on human dignity, it is often emphasized that the clue to the integrity of the human person is a person's integratedness within community life. This is typically expressed with reference to the African notion of ubuntu: A human being is human through other humans (muntu ngumntu ngabantu) .13 We need one another to become fully human. If Descartes suggested that "I think, therefore I am" (cogito ergo Mm), Africans would rather say: "We are related to one another, therefore we are" (cognatud ergodumud).14 This implies an emphasis on each person's honour and dignity, a communal sense of identity, a sense of communal belonging and solidarity, hospitality to visitors, a sharing of land and resources, and an ethos of helping one another in times of need. It suggests an anthropology based on reciprocity, communion, care, responsibility and hospitality. The vision of ubuntu is abused when it masks authoritarian and patriarchal rule in church and society, or when it applied in an exclusivist way to one's own group only. At best, a theological appropriation of the notion of ubuntu would see it not as a romantic dream about a distant agrarian past, but as a moral vision for a dispensation that has never been.

The integrity of the human person is not only a function of an affirmation that human beings have been created in the image of God. The integrity of the human person is also a function of what in ecumenical discourse has been called the "integrity of creation". An important clue to the integrity of the human person is a sense of integration within the community of life, that is, within the earth community.15 J ay McDaniel's definition of the term "integrity of creation" may suffice here: "It refers to the value of all creatures in themselves, for one another, and for God, and their interconnectedness in a diverse whole that has unique value for God."16

\footnotetext{
${ }^{13}$ Although the philosophy of ubuntu is often contrasted with Western individualism (with the danger of an abuse of individual freedom) there are many voices in Western thinking that also emphasize community life (with the danger of authoritarianism). This is for example expressed in the German proverb "Ein Mensch ist kein Mensch."

${ }_{14}$ See, for example, Luke.L. Pato, "Being fully human from the perspective of African culture and spirituality" Journal of Theology for Southern Africa Vol. 97, 1997, pp. 53-61. Also John Pobee, Toward an African theology, Nashville, Tennesse, Abingdon.

${ }^{15}$ See my essay in this regard: Ernst M. Conradie, "On the integrity of the human person and the integrity of creation: Some Christian theological perspectives" in C.W. du Toit (ed.), The integrity of the human person in the African context: Perspectives from science and religion, Pretoria, University of South Africa, 2004, pp. 107-152. It discusses the conceptual difficulties regarding the dignity of each person $s$ life, often based on anthropocen- tric claims for human uniqueness, amidst the integrity of ecosystems where the death of individual specimens is implied in the proper functioning of the food chain.

${ }^{16}$ Jay B. McDaniel, Of God and pelicans: A theology of reverence for life, Westminster, Kentucky, John Knox Press, 1989 , p. 165.
} 
It should be clear that this description of the church's participation in God's mission resonates well with many themes derived from the African context. There is the struggle for survival amidst the many threats to life on the African continent (with specific reference to the scourge of AIDS), the ability to celebrate life amidst scarcity, an appreciation for the joy and vibrancy of life in dance, music and ritual, the ability to mourn the death of others, the emphasis on the integrity of human life and the significant role that many churches continue to play in local community life. Such a description of mission may also be appropriated in numerous other contexts. One of the questions which the working group on theological reflection formulated for further discussion during the Livingstone conference is whether such a description of mission would do justice to the work of churches in other contexts. This question will have to be subjected to further reflection.

Another question that has to be addressed is whether such a description of mission can provide a sense of direction, given the tension that exist between mission as "evangelism" and mission as "development." The next paragraph will offer some further reflections on this question from the perspective of an exegesis of the Lord's Prayer. If mission is a matter of crying and if crying is a form of prayer, mission may well be epitomized by praying the Lord's Prayer.

\section{Perspectives from the Lord's Prayer.}

In a helpful essay on the Lord's Prayer in the Earth Bible series, Vicky Balabanski describes a number of features of the cosmological assumptions reflected in this prayer.17 From a point of departure in her analysis one may identify the following tensions in the structure and implied cosmology of the Lord's Prayer:

a) The prayer is structured around a tension between God's presence in heaven and our presence on earth. The prayer may be read as a plea that the distance between heaven and earth be reduced: God's will needs to be done on earth as it is in heaven. Like heaven, the earth too has to reflect God's name, God reign and God's will.

b) The first word of the prayer is "father" and the last word is "evil". The prayer is therefore situated in the tension between a loving and nourishing parent and the reality of evil, between God's grace and the impact of human sin in society. This tension gives the prayer a soteriological orientation and focus.

c) There is an underlying tension between the already of God's reign and the not yet of the coming of God's reign, between an unacceptable present and a longed-for future.

${ }^{17}$ See Vicky Balabanski, "An Earth Bible reading of the Lord's prayer" in Norman C. Habel (ed), Readings from the perspective of Earth, Cleveland, Ohio, Pilgrim Press, 2002, pp. 151-161. 
d) There is another tension between those who are praying the prayer and those who may overhear the prayer. Who is the "us" who is praying here? In this "us" the needs of the world and the tensions which may exist between "us" and "others" (those who have bread and those who haven't, the indebted and their debtors, the tempters and the tempted, those who are evil and their victims) are brought before God in prayer. In a remarkable but complex way the Lord's Prayer intertwines the relationship between the disciples of Jesus and the outsiders (e.g. the Pharisees), between the church which prays and the world which overhears the prayer. It should also be noted that, in the early church, the Lord's Prayer was prayed in secret during the liturgy. All non-members had to leave the liturgy before the prayer. The prayer was considered so radical, so dangerous, so undermining that it could only be prayed in secret: It called for the radically new world of God's reign.18

e) Perhaps the deepest tension underlying the Lord's Prayer is that between human responsibility and God's responsibility. This is evident from the relationship between the first and the second set of petitions. The first set of petitions is formulated in the form of "Thou petitions". They could be read as being related to "spiritual" matters (perhaps "evangelization"). They focus on God's name, God's reign and God's will. Yet the form of the verbs that are used here ("let your ... be ...") begs the question whose responsibility it would be to carry out what these petitions ask for. It is not difficult to gather that human beings (the church) would be involved in this process. This does not include only those who are praying (otherwise the prayer would be little more than a self-exhortation to do one's duty), but is certainly includes at least those who are praying. The movement in the first set of petitions is therefore from God's presence in heaven towards the earth, from God's work to our work.

By contrast the second set of petitions speaks about concrete daily life here on earth. They speak about bread, about indebtedness (not sin towards God) and the many temptations that the poor are typically subjected to (one may say "development" agendas). These petitions are brought in prayer to the Father. Presumably, humans have in each case done what they could to address their predicament. Of course, it is our own responsibility to ensure that we have bread to eat, to seek reconciliation with other, to offer forgiveness to those who have done something against us and to avoid trouble as far as possible. However, the prayer is apparently born from a situation where the one who prays has done whatever could be done, but realizes that the situation is beyond her or his locus of control. After all, if the one who prays could have done something to remedy the situation, it would not have been necessary to pray for that (unless the

18 See Dirk J Smit, "Matteus 6 9-14' in C W Burger, B A Muller \& D J Smit (eds ) Riglyne vir predikmg oor die bergrede, Kaapstad, Suid-Afhka, N G Kerk-Uitgewers, 1990, p 208 
prayer is again little more than an act of self-exhortation). One would scarcely ask God for bread if one has been too lazy to work for bread for one s own family. The prayer is directed to God because it expresses a trust that it is only God who can still help to address the situation. These observations lead to the somewhat paradoxical conclusion that the second set of petitions shifts the focus onto God's responsibility, whereas the first set of petitions assumes the church's responsibility. The second set of petitions is therefore deeply spiritual (or evangelical) even when the petitions describe material (or developmental) needs. The petitions cry from the earth for God's help.

These observations indicate that to be praying the Lord's Prayer is to be situated within a tension between heaven and earth, God and the world, God's responsibility and our responsibility, grace and gratitude. A life of prayer cannot be separated from a life of gratitude and a life of service to others. One cannot pray these petitions without a willingness to be God's instrument to bring about what has been prayed for. And one cannot work for that which one has not prayed for. This is the deepest secret of the classic Christian motto: Ora et labora.

Following these observations, the second set of petitions in the Lord's Prayer may help us somewhat further in order to integrate the concerns that are typically expressed with the category of "development" with the concern of "evangelism". In the discussion below several layers of meaning of the symbols of bread, debt and temptation will be analyzed. These layers of meaning indicate the inner dialectic between material needs ("development"?) and spiritual needs ("evangelism"?). If one takes one's point of departure in people's more immediate material needs, one would soon have to address to their spiritual needs as well. The opposite would also be true. For the sake of the illustration, only the first approach will be discussed here with reference to the second set of petitions in the Lord's Prayer.

\section{a) A spiritualized interpretation}

There is a widespread tendency to spiritualize the meaning of the symbols of bread, debt, temptation and evil. Accordingly, "bread" refers here to our need for J esus, the "bread of life", or for the bread of the Holy Communion or the feast of eternal life. Similarly, debt is understood as our guilt before God that God is requested to forgive. Temptation is understood as the danger of apostasy, of losing one's faith, especially in the age of the expected "great tribulation." If so, there is a need to be rescued from the diabolic power of Satan.

\section{b) A material layer of meaning}

In response to such a spiritualizing of these symbols one may need to emphasize their concreteness within everyday life, especially within the context of poverty. 
Accordingly, the prayer addresses our bodily need for bread (or rice or maize but not for cake). Many exegetes have noted that the elusive temporal indication epiousios may be translated with "eternal", with "daily" (the minimum that is necessary for today) but also with "for tomorrow." In the last case, the prayer expresses the uncertainty of a father who simply does not know where he will find food for his family tomorrow.19 It is at least clear that the prayer assumes a context of poverty. Jesus and his disciples travelled around without a home, belongings, basic provisions or a regular income. The early Christians who prayed this prayer were typically poor folk, many of whom were slaves, impoverished peasants, fishermen or day-labourers who were standing around in the market-place hoping for employment for the day.

Several exegetes suggest that the Greek term ta opheikmata is probably a translation of the Aramaic cboba which is used in the context of trade and therefore has financial connotations. It does not refer primarily to guilt, also not guilt before God, but to financial indebtedness. The Greek verb aphieimi which is typically translated as "forgive" literally means "to take away", "to wipe out". The metaphor therefore suggests the need for a cancellation of debts, the need to be released from the burden of debts that have accumulated to the point that one cannot escape from permanent indebtedness. Accordingly, the indebtedness does not refer to guilt in our relationship with God (this is not mentioned in the text), but to the burden financial indebtedness to other people - which God is called upon to help cancel.

In a context of hunger and indebtedness there are many all too real temptations (peircumos) to secure bread and money in one's pocket. Those who are hungry may easily be tempted to resort to begging, stealing, prostitution, gangsterism, drug trafficking, or alcohol in order to secure bread. But this will trap them even further in the structures of evil that lurk around them. Indeed, evil would be lurking everywhere and many could be easily trapped in a spiral of increasing violence. The prayer to be protected and delivered from evil makes perfect sense in such a context.

This material layer of meaning does not necessarily exclude a more symbolic meaning. It may be helpful here to remember that a symbol (unlike a metaphor or a sign) always participates in that which it symbolizes. A road sign "Cape Town $460 \mathrm{~km}$ " does not form part of Cape Town, although it does refer to Cape Town. By contrast, the bread that the disciples shared with J esus during the last supper before his death did fill their stomach but also "fed" them in ways that they could scarcely imagine at that time.

\footnotetext{
${ }^{19}$ See Leonardo Boff, The Lord's prayer: The prayer of integral liberation, Maryknoll, New York, Orbis Books, 1983, p.78-83. Also David J Bosch, The Lord's prayer: paradigm, for a Christian lifestyle, Pretoria, South Africa: Christian medical fellowship, 1985, p.27.
} 


\section{c) A social layer of meaning}

The connotations of the symbols of bread, debt and temptation should not be extended too quickly. To suggest that bread is a symbol for all our material needs may easily become an excuse to justify one's desires for luxuries in the name of basic needs. There are nevertheless indications in the text that "bread" is a symbol for more than just food (but certainly including bread). It may be helpful to gain more clarity on the question who are included in the "us" who are praying here. One may assume that the "us" would include at least the nuclear family. An impoverished father is praying to the heavenly father to provide food for his family since he is unable to do so himself. A family does not need only food though. Luther was probably correct in suggesting that "bread" is a symbol for everything that is necessary to sustain life: food, something to drink, clothes, shoes, bodily health, good weather with sufficient sun and rains, chickens, goats, sheep or cattle, land, housing, a good husband or wife, pious children, good friends, reliable neighbours, good governance and peace.20 Although there may be some debate about "basic human needs" it is clear that the temptation to add luxuries has to be resisted here. The most basic of needs include food, clean drinking water, unpolluted air and warm clothing in cold climates.

In the same way, one may extend the meaning of indebtedness. We do not only owe others money. We owe our spouses, children, family members and neighbours numerous other things: a helping hand, time, borrowed items, a favour in return, opportunities and friendship. These duties towards others do not necessarily suggest ways in which we have been guilty in our thoughts, attitudes, body language, words or actions towards others. However, the boundary between being a victim of indebtedness and being guilty in any of these ways is easily crossed. Often our sense of guilt towards others has piled up to such an extent that we do not know where to start rectifying soured relationships. The quickest route to souring relationships probably remains financial indebtedness though. Likewise, the temptations and evil that surround us apply not only to individuals. One also has to address the temptations that a married couple, a family and a community may have to face.

\section{d) A collective layer of meaning}

It is not difficult to extend the meaning of these symbols much further. Bread can function as a symbol for the entire global economy. There is an urgent need for an economic dispensation that can address unemployment, the gap between the rich and the poor, fair trade, just labour practices, access to education and training, provisions for health care, basic social services, etcetera. Likewise, indebtedness is a function of economic dispensations, as the biblical texts also indicate, for example with reference to the sabbatical year and the J ubilee year in Leviticus 23, Isaiah 61 and Luke 4. This indebtedness may easily be extended

${ }^{20}$ See Smit, "Matteus 6:9-14", op.cit. 206-13. 
to the contemporary problem of the crippling debts of already impoverished countries. In many cases such countries are forced to plant cash crops in order to earn foreign income, instead of using their lands to ensure an adequate production of food for their own inhabitants. In the midst of the air raids on Stuttgart in 1945, Helmut Thielicke preached about collective guilt, the whole mountain of guilt associated with the first and second world wars. The German audience would have gathered that they are both guilty and the victims of such "debts".21 One may also extend the predicament of indebtedness to the victims of slavery, imperialism, colonialism, patriarchal oppression, nationalism, fascism, apartheid and globalized capitalism. Numerous impoverished economies find themselves unable to participate in the global market given their handicap in terms of infrastructure, development, education, training, technology and market opportunities. There are many contemporary manifestations of temptation and evil as well. Here one may consider the major ideologies of our times: colonialism, racism, sexism, classism, anthropocentrism and consumerism. Since each of these ideologies provides an easy classification mechanism they continue to offer tempting ways of addressing societal conflict.

\section{e) An ecological layer of meaning}

A collective layer of meaning for the symbols of bread, debt and temptation may also include an ecological layer of meaning. Here we are faced with numerous problems: Will we be able to provide sufficient bread, rice and maize for the world's still increasing population? Will we be able to adopt sustainable forms of agriculture? Will our grandchildren be able to cope with the legacy of the longterm impact of waste and ecological destruction? How will impoverished countries be able to escape from the ecological consequences of the debt that they find themselves entrapped in? How can we avoid the temptation to exploit renewable and non-renewable natural resources for economic benefit? What if shortages in oil, water and food would lead to increasing regional and international conflict and intermittent wars? Will we be able to avoid the use of nuclear weapons in war and through terrorism for the remainder of human history?22

\section{f) A moral layer of meaning}

The above mentioned layers of meaning (see points b-e) focus on the veiy real needs of poor, marginalized and vulnerable people. The prayer is not meant for those who are overfed or for those who follow or support, directly or indirectly, economic practices that may disadvantage the ability of others to secure bread for themselves. It is certainly not meant for those who have an insatiable demand for more and more luxury consumer goods. It is not aimed at those who cunningly impoverish others through demanding housing rent, interest on

\footnotetext{
${ }^{21}$ Helmut Thielicke, Das Gebet das dk Welt umjpannt, Stuttgart, Quell Verlag, 1953.

${ }^{22}$ See Balabanski, "An Earth Bible reading of the Lord's prayer", op.cit. for an ecological reading of the Lord's prayer.
} 
loans, or through the sale of products to people who simply cannot afford it. The prayer is not meant for those who tempt others (through advertising?) to possess more and more, but for those who do not want to be tempted in the first place. It is not aimed at the perpetrators of evil but for those who long to be delivered from evil. The overfed, ruthless creditors, tempters and evil doers who dare to pray the Lord's prayer expose themselves to be judged by this prayer.

Who on earth may then dare to pray this prayer? Who may be included in the "us" of the prayer? There are indications in the text that it may not be all that easy to distinguish between those who are guilty and their victims. Although the prayer articulates the needs of victims, such victims may easily be guilty, at least partially, of causing their own predicaments. There are beggars who are too lazy to work for their own bread, those who take foolish economic decisions, who borrow money all too easily, perhaps because of greed, who swiftly yield to temptations and who are complicit in doing evil. We sometimes suffer because of our own sins (e.g. through the abuse of alcohol) and sometimes because of the sins of others (most notably through rape), but we often suffer from a situation for which we are at least partially, if not equally, responsible (e.g. marriage conflict, trouble with the neighbours or business feuds).

\section{g) A theological layer of meaning}

The most remarkable layer of meaning is perhaps also the most obvious, namely that these petitions form part of prayer in which something is requested from God. The prayer faithfully awaits a response from God. As I have argued above, such a prayer is born from a realization that something is beyond one's own locus of control. One would only pray for something if one has done one's own duty. One cannot ask for bread if one is too lazy to work for bread. One cannot ask for bread for others if one is unwilling to help them to obtain bread honourably. One cannot ask for a cancellation of one's debts if one refuses to cancel the minor debts of others that may be within one's own locus of control. One can only pray to be shielded from temptation and evil if one does not surround oneself with such temptations and evil.

If, however, one has attended to one's responsibilities but still finds oneself unable to secure bread or trapped in unmanageable debt, then the only way out of such a predicament may be to pray for God's help. What is remarkable about the second set of petitions is that the responsibility is shifted here to God. J esus taught his disciples that they may come to the heavenly Father when they find themselves in such a predicament. They may approach the Father with confidence because this is a Father who created them and cares for them and for the whole earth community.

\section{h) A Christological layer of meaning}

\section{https://repository.uwc.ac.za}


There may be those who would remain sceptical. May we actually expect a response from God to our prayers? Is the distance between God in heaven and our earthly lives not too great (especially after Copernicus and Darwin)? Those who do not know where tomorrow's bread will come from may well wonder whether and how God will provide them with bread. Likewise, those who are concerned with bread for others who are hungry, who are faced with food shortages and realize the need for sustainable forms of agriculture may not be sure what kind of response they may expect from God, if any. For some, praying for bread may be little more than a soliloquy in which they call on themselves and others to work towards a just distribution of food. What, one may ask, can the Father in heaven really do to help us?

Although some may think that the onus will revert to human responsibility here, this would underestimate the scope of the predicament and would not do justice to the nature of the prayer as prayer. Perhaps the deepest layer of meaning in the Lord's Prayer is to discern the ways in which the Father has already helped us. Those who doubt whether God will do something tomorrow may find comfort in what God has done yesterday. The clue here is to reflect on the One who has taught us the prayer: the life, ministry, suffering, death and resurrection of J esus, the Christ. Perhaps those who spiritualize the meaning of the symbols of bread, debt and temptation have retained an element of truth in this regard. Elsewhere the gospels proclaim that J esus Christ is indeed the bread of life, that J esus carried our debts and guilt before God and the world, that J esus faced severe temptations on our behalf, and that J esus conquered evil in the most unlikely and unimaginable way, the way of the cross.

This suggests that spiritual (evangelization?) and material (development?) needs can be distinguished but not separated from one another. In the Lord's Prayer there is a movement from the one to the other.

\section{Conclusion}

These exegetical comments will have to be developed in a more systematic way towards an appropriate missiology for our times. Most of those who attended the Livingstone conference would probably agree that mission is God's work of transformation towards comprehensive well being for the whole earth community and that the church is an instrument in 
God's mission. However, an emphasis on a "multi-dimensional", "holistic" or "integrated" notion of mission does not yet help us to understand the relation between Christian witness (marturia) as kerugma, koinonia and diakonia. This calls for further reflection on the relationship between soteriology and missiology and between God's work and our work.23These questions cannot be addressed here fully. To conclude this essay, I will offer some preliminary comments on the search for an adequate Christian notion of salvation. The comments clearly call for further clarification, but this cannot be addressed within the scope of this essay.

It is crucial to do justice to the rich array of soteriological themes that are employed in the Christian tradition. These include (in random order): liberation in cases of political oppression, victory in cases of severe military threats, rescue in cases of violent attacks, healing in cases of sickness, nourishment amidst food scarcity and famine, protection from danger and threats to one's life and dignity, the establishment of political order in cases of virtual anarchy, wisdom amidst foolishness and a loss of indigenous knowledge, exorcism in cases where evil forces threaten, debt cancellation in cases of crippling debt, restoration in cases of (economic) injustices, reconciliation in cases of family or labour disputes, peace in cases of violent conflict, fellowship in cases of loneliness, rootlessness or alienation, forgiveness in cases of inter-personal or inter-community wrongdoing, and reparation in cases of environmental devastation.

The Christian tradition has tended to conflate these soteriological themes through the use of categories such as salvation, redemption and forgiveness of sins. The problem is that such an integration (or conflation) cannot do justice to the metaphorical roots of each of these soteriological themes and to their implied Sitz im Leben. It is probably fair to say that the Christian gospel promises a sense of comprehensive wellbeing (Klaus Nürnberger24) that can address all the human predicaments listed above. If sin may be understood as the violation of relationships, redemption is the fulfilment of our varied relationships:

However, the richness of the soteriological themes in the Christian tradition should not be reduced. It is especially important to recognize some structural differences between these soteriological themes. Liberation theology has reminded all of us that the message of salvation cannot be reduced to the

\footnotetext{
${ }^{23}$ See Bosch's resistance against an all-inclusive notion of mission and his perceptive Christological and soteriological description of the multidimensional nature of mission, namely with reference to the motifs of incarnation, cross, resurrection, ascension, Pentecost and parousia. Bosch, Transforming mission, op.cit, 512-518.

${ }^{24}$ See Klaus Niirnberger, "Towards a new heaven and a new earth" in J.W. de Gruchy \& C. Villa-Vicencio (eds.), Doing theology in context. South African perspectives, Cape Town, South Africa: David Philip, 1994, p.141.
} 
forgiveness of sins; the gospel also speaks about liberation from the social consequences of sin as manifested in the many evils that thrive in society.25

Nevertheless, it is the same gospel that leads us to recognize human sin as the origin of such evils. God's forgiveness (of human sin) is a crucial way of addressing evil at its human origin. The healing of distorted relationships is only possible through the role of forgiveness. Without forgiveness a destructive cycle of acting in one's own interest prompting revenge may soon emerge. Through forgiveness the vicious cycle can be broken. It provides for a new beginning by freeing both the one who forgives and the one who is forgiven from the consequences of earlier destructive acts. A soteriology that emphasizes liberation from oppression therefore should not eschew the doctrine of justification. In addition, it should be recognized that the new beginning which has become possible through reconciliation does not ensure that evil will not emerge again. It is therefore necessary to reflect on appropriate guidelines for society in order to safeguard the future against evil. Here another set of soteriological themes may be appropriate, including a just social order, leadership structures, wisdom, rules to live by (the function of the Torah) and models that would set examples of a new way of life based on categories such as discipleship, stewardship or priesthood.

On this basis one may suggest, formulated in Christological categories, that the gospel addresses the evil consequences of human sin (God's victory over evil, based on the message of resurrection), the roots of such evil in human sin (our sins are forgiven by God through grace, manifested in the cross of J esus Christ) and a way to live in the present in order to ensure a sustainable future (epitomized in the incarnation, life and ministry of J esus of Nazareth, who demonstrated the full intent of God's law).

It remains necessary to develop the missiological implications of such a soteriology. Perhaps such a soteriology offers a way of integrating the agendas of mission as "evangelism" and mission as "development" in a creative way. This is a crucial ecumenical task which has to be addressed on the road towards the next assembly of the World Council of Churches in Porto Alegre in 2006. In reflecting on the theme of "God, in your grace, transform the world", on the meaning of "transformation", on the act of praying to God and on our responsibility in this regard, we will do well to turn to the Lord's prayer for guidance and inspiration.

${ }_{25}$ See also B. Thlagale, "The anthropology of liberation theology", Journal of Theology for Southern Africa, Vol. 76, p.61. 
* Ernst M. Conradie is an associate professor in the Department of Religion and Theology at the University of the Western Cape where he teaches systematic theology in ethics. He works especially in the field of ecological theology. 